J. AMER. Soc. Hort. ScI. 121(1)164-168. 1996.

\title{
Potassium Fertigation Requirements of Drip-irrigated Strawberry
}

\author{
Earl E. Albregts \\ Gulf Coast Research and Education Center-Dover, University of Florida, 13138 Lewis Gallagher Road, \\ Dover, FL 33527-9664
}

George J. Hochnmth ${ }^{1}$

Horticultural Sciences Department, P. O. Box 110690, University of Florida, Gainesville, FL 32611-0690

Craig K. Chandler ${ }^{2}$

Gulf Coast Research and Education Center-Dover, University of Florida, 13138 Lewis Gallagher Road, Dover, FL 33527-9664

\author{
John Cornell ${ }^{1}$ and Jay Harrison ${ }^{3}$ \\ Department of Statistics, P.O. Box 110560, University of Florida, Gainesville, FL 32611-0560
}

Additional index words. potassium chloride, Fragaria $\times$ ananassa, plant nutrition, leaf tissue, petiole sap analysis

\begin{abstract}
Oso Grande' and 'Sweet Charlie' strawberries (Fragaria $\times$ ananassa Duch.) in 1991-92 and 'Oso Grande' and 'Seascape' in 1992-93 were grown in a $\mathrm{K}$ fertilization study using polyethylene-mulched and fumigated beds. Potassium was injected weekly into the drip irrigation system at $0.28,0.56,0.84,1.12$, and $1.40 \mathrm{~kg} \mathrm{~K} / \mathrm{ha}$ per day. Early, March, and total-season marketable fruit yields were not affected by $\mathrm{K}$ rate during either season. The average fruit weight of ' $O$ so Grande' for the early, March, and total-season harvest periods in the 1992-93 season decreased with increased K rate. For the same harvest periods, 'Seascape' average fruit weight increased, decreased, and did not change, respectively, with increased $\mathrm{K}$ rate. Cull fruit yield during both seasons and fruit firmness during the 1992-93 season were not affected by $K$ rate. Petiole sap, whole leaf, and leaf blade $K$ concentrations increased with increasing $K$ rates on most sampling dates during both seasons. 'Oso Grande' and 'Sweet Charlie' produced similar total marketable fruit yields the first season, but 'Oso Grande' produced higher total yields than 'Seascape' during all harvest periods of the second season.
\end{abstract}

Strawberry production in Florida occurs during the months of November through April on about 2000 ha with a farm-gate value of about 100 million dollars (Freie and Pugh, 1994). The annualhill culture system with raised, polyethylene mulched beds and the soil treated with nematicides or fumigants has been the standard production system since the early 1960s. Overhead sprinkler irrigation has been used to establish transplants, to protect against freeze, and to supply water to the plants. Fertilizer used to be applied broadcast or banded in the plant bed prior to mulching with polyethylene (Albregts and Howard, 1984; Hochmuth et al., 1988). In the late 1980s, growers began to use drip irrigation adopting Univ. of Florida recommendations for the application of water to the strawberry crop, resulting in savings of about $70 \%$ in water application. High water application efficiencies mandated by local water districts accelerated the change from overhead sprinklers to drip irrigation systems. Sprinkler irrigation is still used to establish transplants and for frost protection.

Most growers broadcast some fertilizer before bed preparation with the remainder of the fertilizer applied through the drip system. Growers claim that broadcast fertilizer helps the young plants start faster. However, a study (Albregts et al., 1991a) with fertilizer applied through a drip system within 10 days of transplanting resulted in the same fruiting response as those plants where the fertilizer was incorporated into the bed before fumigation. The

Received for publication 19 May 1995. Accepted for publication 6 Sept. 1995. Florida Agr. Expt. Sta. Journal series, no R-04436. The cost of publishing this paper was defrayed in part by the payment of page charges. Under postal regulations, this paper therefore must be hereby marked advertisement solely to indicate this fact. ${ }^{1}$ Professor.

${ }^{2}$ Associate professor.

${ }^{3}$ Statistician. explanation for this response was that the roots of the bare-root transplants are generally damaged or desiccated by the transplant harvest, storage, and transplanting procedures. The new roots for nutrient absorption are not available and functional until 5 to 10 days after transplanting (personal observation). Under both fertilization systems, nutrients were available to the crop by the time new roots formed. The transplants are sprinkler-irrigated for 10 to 14 days to prevent plant desiccation in the field, since the plants cannot absorb sufficient water until new roots are available.

Previous research on $\mathrm{K}$ fertilization for strawberry fruit production with overhead sprinkler irrigation gave varied responses. Potassium rates of 0 to $156 \mathrm{~kg} \cdot \mathrm{ha}^{-1}$ applied to two soils in a pot study did not result in a strawberry yield response (Dennison and Hall, 1956). In a field study, strawberry fruit yield increased linearly with fertilizer rate using a $6 \mathrm{~N}-3 \mathrm{P}-5 \mathrm{~K}$ fertilizer at 900 to $2700 \mathrm{~kg} \cdot \mathrm{ha}^{-1}$ (Locascio and Thompson, 1960). Lineberry and Collins ( 1942) and Lineberry et al. (1944) did not observe a yield response with $\mathrm{K}$ fertilization of strawberry. Locascio and Saxena ( 1967) used rates of K from 0 to 202 $\mathrm{kg} \cdot \mathrm{ha}^{-1}$ and observed no yield response, but shear resistance (firmness) of fruit decreased with increased $\mathrm{K}$ rate. When up to $50 \%$ of the $\mathrm{N}$ and $\mathrm{K}$ fertilizer was applied through the drip irrigation system, fruit yields increased compared to applying all $\mathrm{N}$ and $\mathrm{K}$ preplant (Locascio et al., 1977; Locascio and Martin, 1985). In a two-yew study with three strawberry cultivars, $\mathrm{K}$ from three sources applied at 0 to 224 $\mathrm{kg} \cdot \mathrm{ha}^{-1}$. gave highest fruit yields at 102 to $160 \mathrm{~kg} \cdot \mathrm{ha}^{-1}$ (Albregts et al., 1991 b).

The studies above bracketed strawberry response to $\mathrm{K}$ fertilization with maximum response to $160 \mathrm{~kg} \cdot \mathrm{ha}^{-1}$, but most were not conducted with drip irrigation and fertigation, and soil test results were not always reported. With modem strawberry growers switching to drip irrigation from sprinklers, there is a need to study $\mathrm{K}$ fertigation and 
relate crop response to $\mathrm{K}$ fertilization with residual soil $\mathrm{K}$ status.

The K uptake by fruiting strawberry for a 180-day growing and fruiting season in Florida, with a fruit yield of $30,000 \mathrm{~kg} \cdot \mathrm{ha}^{-1}$, is approximately $65 \mathrm{~kg} \mathrm{~K} / \mathrm{ha}$ (Albregts and Howard, 1980). This is about $360 \mathrm{~g}$ of $\mathrm{K} / \mathrm{ha}$ per day which can be satisfied from fertilizer $\mathrm{K}$ or plant available $\mathrm{K}$ present in the unfertilized soil. With overhead sprinkler irrigation, many growers broadcast their $\mathrm{K}$ before bed preparation. However, leaching of plant nutrients may be considerable because of excessive rainfall between the time of fertilization and the application of mulch to the bed, or water entering the planting holes and draining through the bed (Albregts and Howard, 1984). Fertigation appears to be a better alternative for application of $\mathrm{K}$ to sandy soils.

The precise $\mathrm{K}$ requirement of fertigated strawberry is undocumented. Our studies were conducted to determine the $\mathrm{K}$ requirements of drip-irrigated and fertigated strawberry and to compare strawberry response to $\mathrm{K}$ fertilization with current $\mathrm{K}$ recommendations based on soil testing.

\section{Materials and Methods}

Research was conducted during the fall through spring production seasons of 199 1-92 and 1992-93 at the Univ. of Florida, Gulf Coast Research and Education Center at Dover on a Seffner fine sand (sandy, siliceous, hyperthermic Quartzipsammentic Haplumbrept). Soil preparation at the research site both seasons began in July with incorporation by rototilling four times of a sorghum-sudan hybrid ('Sweet leaf') cover crop. Soil samples to the $15-\mathrm{cm}$ depth were taken after the final rototilling and analyzed for $\mathrm{pH}, \mathrm{P}, \mathrm{K}, \mathrm{Ca}$, and $\mathrm{Mg}$ concentrations using the Mehlich- 1 extraction methodology (Hanlon et al., 1990). The soil K levels were $27 \mathrm{mg} \cdot \mathrm{kg}^{-1}$ in 1991 and $46 \mathrm{mg} \cdot \mathrm{kg}^{-1}$ in 1992, which are low and medium, respectively, for Florida vegetables (Hanlon et al., 1990; Hanlon and Hochmuth, 1989), and resulted in recommendations of 120 and $75 \mathrm{~kg} \mathrm{~K} / \mathrm{ha}$, respectively for strawberry.

On 16 Sept. 1991 and 14 Sept. 1992, fertilizer was broadcast in the future bed areas. Fertilizer rates were $10 \mathrm{~kg} \mathrm{Mg} / \mathrm{ha}$ from magnesium sulfate, $20 \mathrm{~kg} \mathrm{P} / \mathrm{ha}$ from triple superphosphate, and 1, 1, 2, 2, and $3 \mathrm{~kg} \cdot \mathrm{ha}^{-1} \mathrm{Cu}, \mathrm{B}, \mathrm{Mn}, \mathrm{Zn}$, and $\mathrm{Fe}$, respectively, from sulfate-containing micronutrient fertilizers (B supplied from sodium borate). Beds were formed, fumigated with $400 \mathrm{~kg} \cdot \mathrm{ha}^{-1}$ of a 98\% methyl bromide : $2 \%$ trichloronitromethane (chloropicrin) mixture, and pressed. During bed pressing, drip irrigation tubing (T-Systems, San Diego, Calif.) was positioned in the center of the bed and buried $3 \mathrm{~cm}$ deep. Drip irrigation tubing emitters were spaced $30 \mathrm{~cm}$ apart and had a flow rate of $19 \mathrm{ml} \cdot \mathrm{min}^{-1}$ at $55 \times 10^{3}$ $\mathrm{Pa}$. Pressed beds were then covered with black polyethylene mulch $(0.025 \mathrm{~mm}$ thick). Beds, which were $15 \mathrm{~cm}$ in height and $60 \mathrm{~cm}$ wide, were spaced $1.22 \mathrm{~m}$ apart (bed center to bed center).

On 14 Oct. 1991, 'Oso Grande' and 'Sweet Charlie' strawberry transplants were planted through the mulch in two rows on each bed with $30 \mathrm{~cm}$ between rows and $28 \mathrm{~cm}$ between plants in a row. 'Oso Grande' and 'Seascape' were planted on 11 Oct. 1992. 'Sweet Charlie' plants were grown at the research center in Dover and 'Oso Grande' and 'Seascape' were grown in Canada (Ghesquiere Farms, Simcoe, Ontario). Transplants were irrigated with overhead sprinklers periodically during the day for 2 weeks following transplanting to aid in plant establishment. Plots (experimental units) each consisted of $3.4 \mathrm{~m}$ of bed containing 22 plants.

Fertilizer treatments were $0.28,0.56,0.84,1.12$, and $1.40 \mathrm{~kg} \mathrm{~K} /$ ha per day with seven times the daily rate applied through the drip system once per week. This range of $\mathrm{K}$ application rates was chosen to cover the projected range of crop response even though commercial growers often apply rates of $\mathrm{K}$ outside this range. With each $\mathrm{K}$ injection, $0.84 \mathrm{~kg} \mathrm{~N} / \mathrm{ha}$ per day was included. Fertilizer injection was begun 21 Oct. 1991 and 18 Oct. 1992 and continued for 25 weeks each season. The five $\mathrm{K}$ injection treatments resulted in $50,100,150,200$, and $250 \mathrm{~kg} \mathrm{~K} / \mathrm{ha}$, respectively for the season. The $\mathrm{K}$ source was potassium chloride, and the $\mathrm{N}$ source was a urea and ammonium nitrate solution $\left(16 \%\right.$ urea-N, $8 \% \quad \mathrm{NH}_{4}-\mathrm{N}$, and $8 \%$ $\left.\mathrm{NO}_{3}-\mathrm{N}\right)$. The drip irrigation system was operated periodically for irrigation purposes to maintain soil moisture tension between -5 and $-15 \mathrm{kPa}$ (measured by a tensiometer with the ceramic tip at 15 $\mathrm{cm}$ below the surface of the bed between two plants in a row). Foliar diseases were controlled with timely sprays of captan (Ntrichloromethylthio-4-cyclohexene-1,2-dicarboximide), iprodione [3-(3,5-dichlorophenyl)-5-ethenyl-5-methyl-2,4-oxazolidinedione], and elemental sulfur.

Whole-leaf (blades plus petiole) samples (20 leaves) of 'Oso Grande' were collected on 19 Nov.. 9 and 31 Dec., 18 Feb., 23 Mar., and 13 Apr. in the 1991-92 season and on 14 Dec., 4 and 25 Jan., 16 Feb., 9 and 31 Mar., and 14 Apr. 1992-93. Samples consisting of leaf blades only of 'Oso Grande' were collected on 14 Dec. 1992, and on 4 and 25 Jan., 9 and 31 Mar., and 14 Apr. 1993. Leaf petioles were excised from 10 randomly selected leaves of the 20-leaf sample. The petioles were chopped and the sap expressed by a hydraulic press (HACH Co., Loveland, Colo.). The fresh petiole sap was analyzed for nitrate- $\mathrm{N}$ and $\mathrm{K}$ concentrations using battery-operated, hand-held ion-specific electrodes (Horiba, Kyoto, Japan). The remaining 10 whole leaves and leaf blades were dried in an oven at $65 \mathrm{C}$ for 3 days and ground in a Wiley mill. A 0.5-g sample was digested in sulfuric acid and hydrogen peroxide. $\mathrm{K}$ was determined by plasma emission spectrometry (Hanlon and DeVore, 1989; Jones, 1977).

Fruits with at least $75 \%$ red color were harvested twice weekly, and separated into marketable and cull categories. Marketable fruits were those fruits free of rot, well-shaped (conical or flatwedge), and weighing $10 \mathrm{~g}$ or more. Fruits in each category were counted and weighed. Harvesting for 'Sweet Charlie' and 'Oso Grande' in the first season began on 19 Dec. 1991 and ended on 30 Apr. 1992. Harvesting for 'Seascape' and 'Oso Grande' began on 9 Nov. 1992 and 4 Jan. 1993, respectively, in the second season and ended for both cultivars on 30 Apr. 1993. Firmness of the area just below the shoulder of ripe 'Seascape' and 'Oso Grande' fruits was measured with a Chatillon model DPP press with a 6-mm wedgeshaped tip. Readings were made when the tip punctured the fruit to a depth of $4 \mathrm{~mm}$. Firmness measurements were made on 8 Apr. 1992, and on 25 Feb., 11 Mar., and 6 Apr. 1993.

Table 1. Monthly rainfall and temperature averages for the two seasons of strawberry production.

\begin{tabular}{llllllllll}
\hline \hline & & Oct. & Nov. & Dec. & Jan. & Feb. & Mar. & Apr. & Season \\
\hline 1991-92 Rainfall & $(\mathrm{mm})$ & 16 & 43 & 40 & 37 & 112 & 42 & 58 & Total $=348$ \\
Temperature $(\mathrm{C})^{2}$ & 23.8 & 18.1 & 18.5 & 15.1 & 18.0 & 19.5 & 20.9 & Avg $=19.1$ \\
1992-93 Rainfall & $(\mathrm{mm})$ & 78 & 60 & 22 & 128 & 52 & 112 & 80 & Total $=532$ \\
Temperature $(\mathrm{C})$ & 22.5 & 21.2 & 17.2 & 19.0 & 15.5 & 17.6 & 19.7 & Avg $=19.0$ \\
\hline
\end{tabular}

${ }^{2}$ Temperature recorded $60 \mathrm{~cm}$ above soil surface in protected recording box. 
Table 2. Effects of $\mathrm{K}$ fertilization and cultivar on strawberry fruit yield, quality, and size during two seasons at Dover, Fla.

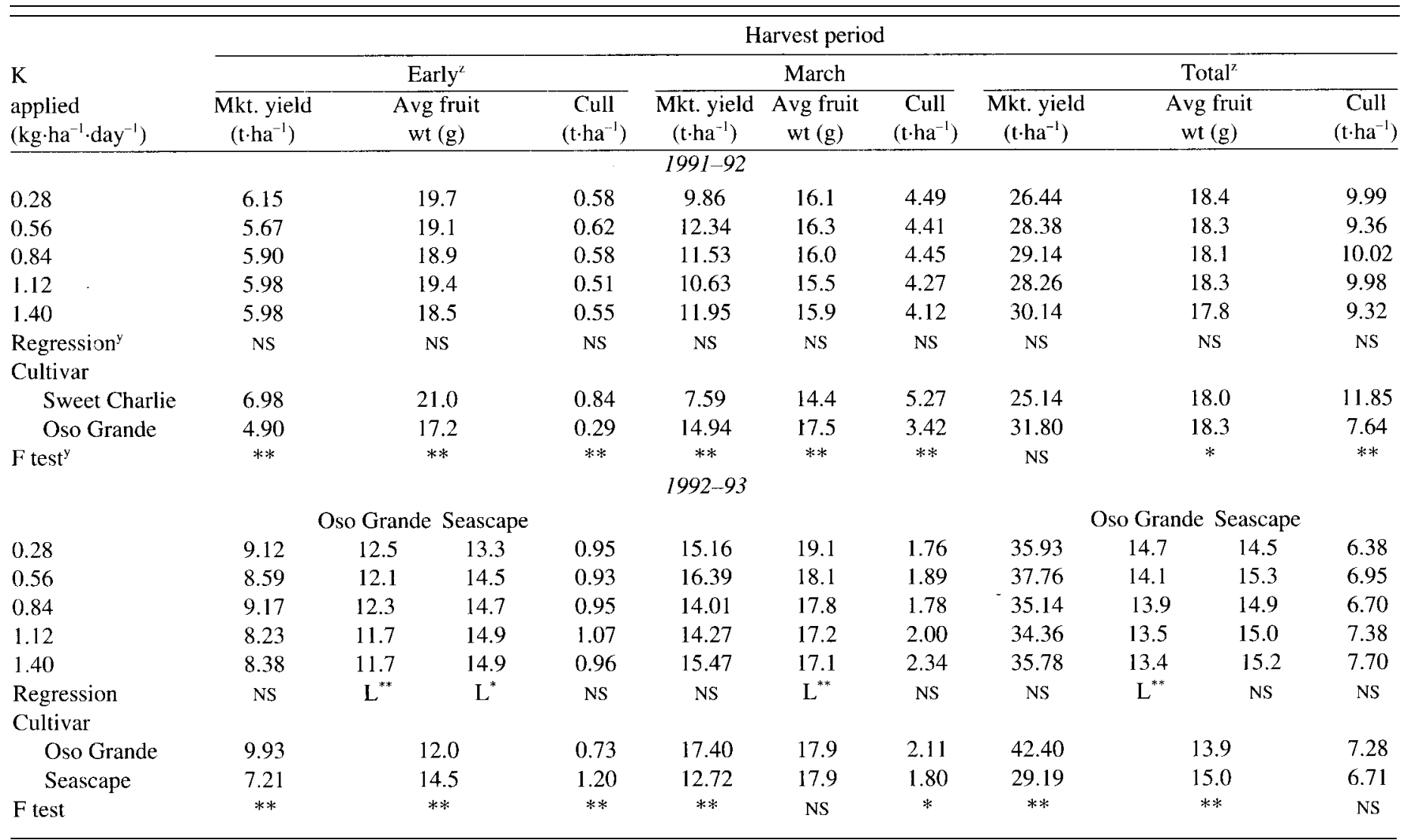

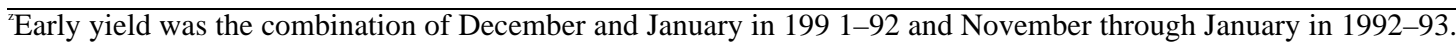

${ }^{x}$ Interaction of rate and cultivar significant.

${ }^{\mathrm{Ns}}, *, * *$ Nonsignificant or significant at $\mathrm{P}<0.05$ or 0.01 , respectively; $\mathrm{L}=$ linear.

The study was a split-plot experiment arranged in a randomized complete-block design with $\mathrm{K}$ fertilization rates as main-plot treatments and cultivars as subplot treatments. Main-sub treatment combinations were replicated four times the first year and five times the second year. Data were analyzed using SAS procedures ANOVA and GLM (SAS Inst., Cary, N.C.). Responses to $\mathrm{K}$ rates were modeled using linear and quadratic regression equations.

\section{Results}

Plants during the 1992-93 season received 50\% more rainfall than during the $1991-92$ season, but the average temperature was similar both seasons (Table 1). Temperatures both seasons were conducive to optimum strawberry growth and yield, and rainfall events would not have been expected to cause $\mathrm{K}$ leaching of mulched crops on this sandy soil.

Marketable fruit yields for both seasons and all harvest periods were not significantly affected by $\mathrm{K}$ rates (Table 2 ). $\mathrm{K}$ at 0.28 $\mathrm{kg} \cdot \mathrm{ha}^{-1}$ per day was adequate for maximum yield of strawberries in both experiments. The soil-K was rated low in 1991-92, yet no response to $\mathrm{K}$ was observed. It is possible that the current interpretation of the soil test values is not accurate and that soils testing 27 $\mathrm{mg} \cdot \mathrm{kg}^{-1} \mathrm{~K}$ should be placed in a higher (medium or high) category.

During the first season, the 'Sweet Charlie' cultivar had higher earl y marketable fruit yield than 'Oso Grande' while 'Oso Grande' had higher marketable fruit yields in the March harvest (Table 2). Total-season fruit yields in the first season were similar for both cultivars. For the second season, 'Oso Grande' had higher marketable fruit yields than 'Seascape' during all harvest periods. These responses of these three cultivars are typical of their relative responses under Florida conditions although the responses could have been affected by the fact that plants originated in nurseries in varying climates.

During the first season, the average fruit weights for both cultivars were not affected by $\mathrm{K}$ rates. During the second season, there was an interaction between cultivar and $\mathrm{K}$ rate for early and for seasonal average fruit weight (Table 2). For early season yield, 'Oso Grande' fruit weight decreased linearly while 'Seascape' fruit weight increased linearly with increasing $\mathrm{K}$ rate. For the March harvest period, the average fruit weight for both cultivars

Table 3. Main effects of $\mathrm{K}$ fertilization and cultivar on strawberry fruit firmness as measured on three dates, 1992-93 season.

\begin{tabular}{lccc}
\hline \hline K applied & \multicolumn{3}{c}{ Sampling date } \\
\cline { 2 - 4 }$\left(\mathrm{kg} \cdot \mathrm{ha}^{-1} \cdot\right.$ day $\left.^{-1}\right)$ & 25 Feb. & 11 Mar. & 6 Apr. \\
\hline \multicolumn{4}{c}{ Firmness $(N)$} \\
0.28 & 1.60 & 2.03 & 1.47 \\
0.56 & 1.56 & 1.90 & 1.39 \\
0.84 & 1.55 & 1.91 & 1.51 \\
1.12 & 1.53 & 1.86 & 1.44 \\
1.40 & 1.51 & 2.01 & 1.38 \\
Regression & NS & NS & NS \\
Cultivar & & & \\
Oso Grande & 1.62 & 2.14 & 1.51 \\
Seascape & 1.50 & 1.74 & 1.36 \\
ANOVA & NS & $* *$ & $*$ \\
\end{tabular}

${ }_{\mathrm{Ns}}, * *$ Nonsignificant at significant at $P \leq 0.01$, respectively. 
Table 4. Main effects of K fertilization on K concentration of 'Oso Grande' strawberry leaf blades, 1992-93 season.

\begin{tabular}{lccccccc}
\hline \hline $\mathrm{K}$ & \multicolumn{7}{c}{ Sampling date } \\
\cline { 2 - 8 } $\begin{array}{l}\text { applied } \\
\left(\mathrm{kg} \cdot \mathrm{ha}^{-1} \cdot \text { day }^{-1}\right)\end{array}$ & 14 Dec. & 4 Jan. & 25 Jan. & 16 Feb. & 9 Mar. & 31 Mar. & 14 Apr. \\
\cline { 2 - 8 } & 16.1 & 15.6 & 13.6 & 12.8 & 12.3 & 9.6 & 9.6 \\
0.28 & 18.4 & 20.4 & 17.2 & 14.6 & 15.2 & 13.7 & 12.4 \\
0.56 & 19.6 & 22.7 & 18.3 & 14.9 & 17.5 & 16.5 & 17.0 \\
0.84 & 20.7 & 22.8 & 19.3 & 17.6 & 19.3 & 20.5 & 19.5 \\
1.12 & 20.9 & 22.3 & 20.4 & 18.0 & 20.0 & 21.4 & 20.3 \\
1.40 & $\mathrm{~L}^{* *} \mathrm{Q}^{*}$ & $\mathrm{~L}^{* *} \mathrm{Q}^{* *}$ & $\mathrm{~L}^{* *} \mathrm{Q}^{*}$ & $\mathrm{~L}^{* *}$ & $\mathrm{~L}^{* *} \mathrm{Q}^{*}$ & $\mathrm{~L}^{* *}$ & $\mathrm{~L}^{* *}$ \\
Regression & & &
\end{tabular}

***Significant at $\mathrm{P}=0.05$ or 0.01 , respectively; $\mathrm{L}=$ linear and $\mathrm{Q}=$ quadratic. fertilization with $\mathrm{K}$ might reduce fruit value and profits since large fruits are preferred for the fresh strawberry market.

During both seasons, the early-season, March, and total-season cull yields were not significantly affected by $\mathrm{K}$ rates (Table 2 ). 'Sweet Charlie' plants had significantly more cull fruit than 'Oso Grande' plants for the early, March, and total-season fruiting periods during the 199 1-92 season. In the second season, cull fruit yields were significantly higher with 'Seascape' early in the season and with 'Oso Grande' at the March harvest period. Yields of cull fruits were equal with both cultivars for the total season.

The effect of $\mathrm{K}$ rate on the firmness of strawberry fruit was determined on one date in 1991-92 and on three dates during the 1992-93 season. Fruit firmness was not affected by K rates used in this study. Oso Grande' fruit were found to have higher average firmness than 'Seascape' on the last two sampling dates of 1992-93 ) (Table 3).

Leaf-blade, petiole-sap, and whole-leaf $\mathrm{K}$ concentrations in-

Table 5. Strawberry ('Oso Grande') petiole sap and whole-leaf K concentrations in response to K fertilization of strawberries during two seasons.

\begin{tabular}{|c|c|c|c|c|c|c|c|c|}
\hline \multirow{2}{*}{$\begin{array}{l}\mathrm{K} \\
\text { applied } \\
\left(\mathrm{kg} \cdot \mathrm{ha}^{-1} \cdot \mathrm{day}^{-1}\right.\end{array}$} & \multicolumn{8}{|c|}{$\mathrm{K}$ concn } \\
\hline & $\begin{array}{l}\text { Petiole sap } \\
\left(\mathrm{mg} \cdot \mathrm{liter}^{-1}\right)\end{array}$ & $\begin{array}{l}\text { Whole leaf } \\
\left(\mathrm{g} \cdot \mathrm{kg}^{-1}\right)\end{array}$ & $\begin{array}{l}\text { Petiole sap } \\
\left(\mathrm{mg} \cdot \text { liter }^{-1}\right)\end{array}$ & $\begin{array}{c}\text { Whole leaf } \\
\left(\mathrm{g} \cdot \mathrm{kg}^{-1}\right)\end{array}$ & $\begin{array}{l}\text { Petiole sap } \\
\left(\mathrm{mg} \cdot \text { liter }^{-1}\right)\end{array}$ & $\begin{array}{c}\text { Whole leaf } \\
\left(\mathrm{g} \cdot \mathrm{kg}^{-1}\right)\end{array}$ & $\begin{array}{l}\text { Petiole sap } \\
\left(\mathrm{mg}^{-} \text {liter }^{-1}\right)\end{array}$ & $\begin{array}{c}\text { Whole leaf } \\
\left(\mathrm{g} \cdot \mathrm{kg}^{-1}\right)\end{array}$ \\
\hline \multicolumn{9}{|c|}{$1991-92$} \\
\hline & \multicolumn{2}{|c|}{$19 \mathrm{Nov}$} & \multicolumn{2}{|c|}{$9 \mathrm{Dec}$} & \multicolumn{2}{|c|}{31 Dec. } & \multicolumn{2}{|c|}{$18 \mathrm{Feb}$} \\
\hline 0.28 & $2350^{y}$ & $28.0^{y}$ & 3250 & 29.0 & 2250 & 25.3 & 1425 & 20.3 \\
\hline 0.56 & 2700 & 32.0 & 3150 & 30.5 & 2500 & 29.8 & 1750 & 24.00 \\
\hline 0.84 & 2950 & 32.0 & 3450 & 32.0 & 2500 & 31.0 & 2000 & 25.3 \\
\hline 1.12 & 3200 & 32.0 & 3650 & 31.0 & 2500 & 30.5 & 1875 & 25.5 \\
\hline 1.40 & 3050 & 31.0 & 3850 & 31.0 & 2775 & 32.3 & 2175 & 26.0 \\
\hline Response & NS & NS & NS & NS & NS & $\mathrm{L}^{* *}$ & $\mathrm{~L}^{* *}$ & $\mathrm{~L}^{* *}$ \\
\hline & \multicolumn{2}{|c|}{23 Mar. } & \multicolumn{2}{|c|}{$13 \mathrm{Apr}$} & & & & \\
\hline 0.28 & 880 & 13.5 & 880 & 12.8 & & & & \\
\hline 0.56 & 1300 & 18.0 & 1350 & 17.0 & & & & \\
\hline 0.84 & 1725 & 27.5 & 1925 & 22.0 & & & & \\
\hline 1.12 & 1875 & 26.5 & 2075 & 26.0 & & & & \\
\hline 1.40 & 2050 & 29.0 & 2475 & 28.5 & & & & \\
\hline Response & $\mathbf{L}^{* *}$ & $\mathrm{~L}^{*}$ & $\mathrm{~L}^{* *}$ & $\mathrm{~L}^{* *}$ & & & & \\
\hline \multirow[t]{2}{*}{$1992-93$} & & & \multirow{2}{*}{\multicolumn{2}{|c|}{4 Jan. }} & \multirow{2}{*}{\multicolumn{2}{|c|}{$25 \mathrm{Jan}$}} & \multirow{2}{*}{\multicolumn{2}{|c|}{$16 \mathrm{Feb}$}} \\
\hline & \multicolumn{2}{|c|}{$14 \mathrm{Dec}$} & & & & & & \\
\hline 0.28 & $1440^{2}$ & $20.7^{z}$ & 1720 & 18.4 & 2120 & 16.3 & 2040 & 15.9 \\
\hline 0.56 & 2540 & 23.5 & 2060 & 22.9 & 1840 & 20.4 & 2240 & 18.1 \\
\hline 0.84 & 2620 & 25.6 & 2380 & 26.1 & 1840 & 22.1 & 2480 & 20.2 \\
\hline 1.12 & 3060 & 26.5 & 2680 & 27.1 & 2160 & 22.1 & 3280 & 21.1 \\
\hline 1.40 & 3000 & 26.5 & 2480 & 26.3 & 2380 & 25.4 & 3340 & 21.5 \\
\hline \multirow[t]{2}{*}{ Response } & $\mathrm{L}^{* *}$ & $\mathrm{~L}^{* *}$ & $\mathrm{~L}^{* *}$ & $\mathrm{~L}^{* *}$ & $\mathrm{~L}^{*}$ & $\mathrm{~L}^{* *}$ & $\mathrm{~L}^{* *}$ & $\mathrm{~L}^{* *}$ \\
\hline & \multicolumn{2}{|c|}{9 Mar. } & \multicolumn{2}{|c|}{31 Mar. } & \multicolumn{2}{|c|}{ I4 Apr } & & \\
\hline 0.28 & 1620 & 13.5 & 850 & 9.7 & 980 & 9.5 & & \\
\hline 0.56 & 2380 & 18.0 & 2000 & 15.9 & 1280 & 16.1 & & \\
\hline 0.84 & 2500 & 21.1 & 2560 & 20.3 & 1980 & 21.7 & & \\
\hline 1.12 & 2520 & 21.7 & 2880 & 26.7 & 2360 & 27.3 & & \\
\hline 1.40 & 2580 & 22.4 & 3240 & 27.3 & 2360 & 26.6 & & \\
\hline Response & $\mathrm{L}^{* *}$ & $\mathrm{~L}^{* *}$ & $\mathrm{~L}^{* *}$ & $\mathrm{~L}^{* *}$ & $\mathrm{~L}^{* *}$ & $\mathbf{L}^{* *}$ & & \\
\hline
\end{tabular}

${ }^{\overline{2}}$ Values are means of four replicates in 1991 -92 and five replicates in 1992-93.

${ }^{\text {ns }}, *, * *$ Nonsignificant or significant at $P \leq 0.05$ or 0.01 , respectively; $\mathrm{L}=$ linear. 
creased with increased $\mathrm{K}$ rate (Tables 4 and 5). Ulrich et al. ( 1980) reported $10 \mathrm{~g} \cdot \mathrm{kg}^{-1}$ as the critical concentration for $\mathrm{K}$ in leaf blades of fruiting strawberry. This is a value at which no $\mathrm{K}$ deficiency symptoms occur. Florida researchers reported $11 \mathrm{~g} \cdot \mathrm{kg}^{-1}$ as the critical concentration for leaf blades (Albregts and Howard, 1984; Hochmuth et al., 1988). Leaf-blade K concentrations during the last season (Table 4) and petiole sap and whole-leaf $\mathrm{K}$ concentrations during the both seasons (Table 5) decreased with time. On 31 Mar. 1993 and 14 Apr. 1993, the leaf blade and the whole leaf K concentrations were below $11 \mathrm{~g} \cdot \mathrm{kg}^{-1}$ for the $0.28 \mathrm{~kg} \cdot \mathrm{ha}^{-1}$ treatment. No significant fruit yield or fruit quality differences occurred, however. Perhaps the reduction in $\mathrm{K}$ concentrations in the petiole and leaf occurred too late in the season to influence fruit yields. Additional research is needed to verify the $\mathrm{K}$ needs of the plant during the latter part of the harvest season.

In conclusion, potassium fertilizer rate of $0.28 \mathrm{~kg} \mathrm{~K} / \mathrm{ha}$ per day or above had no effect on early, March, or total-season fruit yields. Perhaps the $\mathrm{K}$ recommendations for crops on these soils were too high or the drip irrigation system with fertilizer injection is more efficient than the previous method of fertilization with all fertilizers applied before planting. Application of $50 \mathrm{~kg} \mathrm{~K} / \mathrm{ha}$ for both strawberry crops was sufficient when either 120 or $75 \mathrm{~kg} \mathrm{~K} / \mathrm{ha}$ were recommended for the first and second seasons, respective $\mathrm{y}$. This low crop requirement for $\mathrm{K}$ shows that $\mathrm{K}$ recommendations for fertigated-strawberries could be reduced compared to current $\mathrm{K}$ recommendations, which were developed with all $\mathrm{K}$ applied preplant. High rates of $\mathrm{K}$ reduced the early and seasonal average fruit weight of 'Oso Grande' but increased the early season average fruit weight of 'Seascape'. $\mathrm{K}$ fertilization may need to be specific for the cultivar to maximize the average fruit weight. Sap testing for $\mathrm{K}$ was a very rapid and fairly simple procedure that could be done by the grower. It may be of benefit to the grower in determining and adjusting the crop $\mathrm{K}$ needs during the vegetative and crop production stages.

\section{Literature Cited}

Albregts, E. E., G.A. Clark, C.D. Stanley, F.S. Zazueta, and A.G. Smajstrla. 199 1a. Preplant fertilization of fruiting microirrigated strawberry. HortScience 26:1176-1177.

Albregts, E.E. and C.M. Howard. 1980. Accumulation of nutrients by strawberry plants and fruit grown in annual hill culture. J. Amer. Soc. Hort. Sci. 105:386-388.

Albregts, E.E. and C.M. Howard. 1984. Strawberry production in Florida. Fla. Agr. Expt. Sta. Bul. 841.

Albregts, E. E., C.M. Howard, and C.K. Chandler. 199 lb. Effect of potassium sources and rates on fruiting response of three strawberry clones. Adv. Strawberry Prod. 10:37-39.

Dennison, R.A. and C.B. Hall. 1956. Influence of nitrogen, phosphorus, potash, and lime on the growth and yield of strawberries. Proc. Fla. State Hort. Soc. 69:224-228.

Freie, R.L. and N.L. Pugh. 1994. Florida Agricultural Statistics, Vegetable Summary 1992-93. Fla. Agr. Stat. Serv., Orlando.

Hanlon, E.A. and J.M. DeVore. 1989. IFAS Extension soil testing laboratory chemical procedures and training manual. Fla. Coop. Ext. Serv. Circ. 812.

Hanlon, E.A. and G.J. Hochmuth. 1989. Fertilizer recommendations for vegetables grown on polyethylene mulch. Proc. 21st Natl. Agr. Plastics Cong. 21:165-171.

Hanlon, E. A., G. Kidder, and B.L. McNeal. 1990. Soil, container media and water testing. Interpretations and IFAS standardized fertilization recommendations. Fla. Coop. Ext. Serv. Circ. 817.

Hochmuth, G. J., D.N. Maynard, and M. Sherman. 1988. Strawberry production guide for Florida. Fla. Coop. Ext. Serv. Circ. 142C.

Jones, J.B., Jr. 1977. Elemental analysis of soil extracts and plant tissue ash by plasma emission spectroscopy. Cornmun. Soil Sci. Plant Anal. 8:345-365.

Lineberry, R. A., L. Burkart, and E.R. Collins. 1944. Fertilizer requirement of strawberries on new land in North Carolina. Proc. Amer. Soc. Hort. Sci. 45:283-292.

Lineberry, R.A. and E.R. Collins. 1942. Fertilizing strawberries in North Carolina. N.C. Agr. Expt. Sta. Bul. 332.

Lecascio, S.J. and F.G. Martin. 1985. Nitrogen source and application timing for trickle-irrigated strawberries. J. Amer. Soc. Hort. Sci. 110:820-823.

Locascio, S. J., J.M. Myers, and F.G. Martin. 1977. Frequency and rate of fertilization with trickle irrigation for strawberries. J. Amer. Soc. Hort. Sci. 102:456-458.

Locascio, S.J. and G.K. Saxena. 1967. Effects of potassium source and rate and nitrogen rate on strawberry tissue composition and yield. Proc. Fla. State Hort. Soc. 80:173-176.

Locascio, S.J. and B.D. Thompson. 1960. Strawberry yield and soil nutrient levels as affected by fertilizer rate, type of mulch, and time of application. Proc. Fla. State Hort. Soc. 73:172-179.

Ulrich, A., M.A.E. Mostafa, and W.W. Allen. 1980. Strawberry deficiency symptoms: A visual and plant analysis guide to fertilization: Publ. no. 4098, Div. of Agr. Sci., Univ. of Calif. 